\title{
NEW RECORDS OF TAPIRUS FROM THE LATE PLEISTOCENE OF SOUTHWESTERN AMAZONIA, BRAZIL
}

\author{
ELIZETE CELESTINO HOLANDA \\ Curso de Pós Graduação em Geociências, Instituto de Geociências, UFRGS. \\ Museu de Ciências Naturais, FZBRS, Porto Alegre, RS, Brazil.elizeteholanda@yahoo.com.br \\ MARIO ALBERTO COZZUOL \\ Laboratório de Biologia Evolutiva e da Conservação, UNIR, Porto Velho, RO. \\ MCT-PUCRS, Av. Ipiranga 6681, 90619-900, Porto Alegre, RS, Brazil.mario.cozzuol@pucrs.br
}

\begin{abstract}
The genus Tapirus has four living species and a disjunct distribution (America and Asia). Its fossil record extends back to the Oligocene in Europe and middle Miocene in North America, with more than 20 nominal species. We describe here three specimens from the Pleistocene of Rondônia and Acre states, southwestern Amazonia. Morphometric analysis indicates the presence of two morphotypes for the genus, which are different from the recent ones: a robust form, represented by Acre specimens, and a more gracile form represent by the specimens from Rondônia.
\end{abstract}

Key words: Tapirus, Pleistocene, Southwestern Amazonia.

RESUMO - O gênero Tapirus possui hoje uma distribuição disjunta (Américas e Ásia) e somente quatro espécies. No passado, ao contrário, seu registro estende-se até o Oligoceno da Europa e o Mioceno médio do norte da América do Norte, com um número superior a 20 espécies. Apresenta-se aqui o registro de três novos espécimes para o Pleistoceno dos Estados de Rondônia e Acre, Amazônia Sul-Ocidental. A análise morfométrica mostrou tratarem-se de dois morfotipos de Tapirus sp., diferentes das espécies neotropicais atuais: uma forma robusta, representada pelos espécimes do Estado do Acre, e uma forma grácil representada pelo espécime do Estado de Rondônia.

Palavras-chave: Tapirus, Pleistoceno, Amazônia Sul-Ocidental.

\section{INTRODUCTION}

The family Tapiridae is presently composed of a single genus, Tapirus Brünnich, 1772 with four living species, distributed in the Americas and southeastern Asia. Tapirus indicus Desmarest, 1819, is found in southeast Asia (Nowak, 1997). Tapirus bairdii (Gill, 1865) from southeast Mexico to the northwestern Andes (Eisenberg \& Redford, 1989). Tapirus pinchaque (Roulin, 1829), the mountain tapir, is adapted to andean highlands between southern Colombia and northernmost Peru (Downer, 1997). Tapirus terrestris (Linnaeus, 1758), the lowland tapir, is the most widely distributed species, found in northern South America eastern of the Andes, southward to northern Argentina (Bodmer \& Brooks, 1997).

The oldest record for the genus is in the Oligocene of Europe. It persisted in that continent until the Pliocene (Radinsky, 1965). In North America the record starts in the middle Miocene extending to the Recent; by the Recent it is restricted to Mexico (Hulbert, 1995). In Asia the oldest record is from the Pliocene and extends to the Recent (Hulbert, 1995; Figure 1).

In South America the genus appears during the Ensenadan South American Land Mammal Age (SALMA), late Pliocene to early Pleistocene (Cione \& Tonni, 1996; Tonni et al., 1999; Nabel et al., 2000), persisting today.

The European tapirs are closer to T. indicus than to the American species and the extinct South American species seems to be close to T. bairdii (Tonni, 1992). According to Ashley et al. (1996) and Norman \& Ashley (2000), mithocondrial cytochrome c oxidase subunit II and gene $12 \mathrm{~S}$ rRNA sequences indicate a closer relationship between $T$. terrestris and $T$. pinchaque, suggesting a single South American colonization during the Great American Biotic Interchange (GABI) and subsequent divergence.

The goal of this paper is to report recent records of species of the genus Tapirus for the southwestern Amazonia and discuss their affinities with recent and fossil species. 


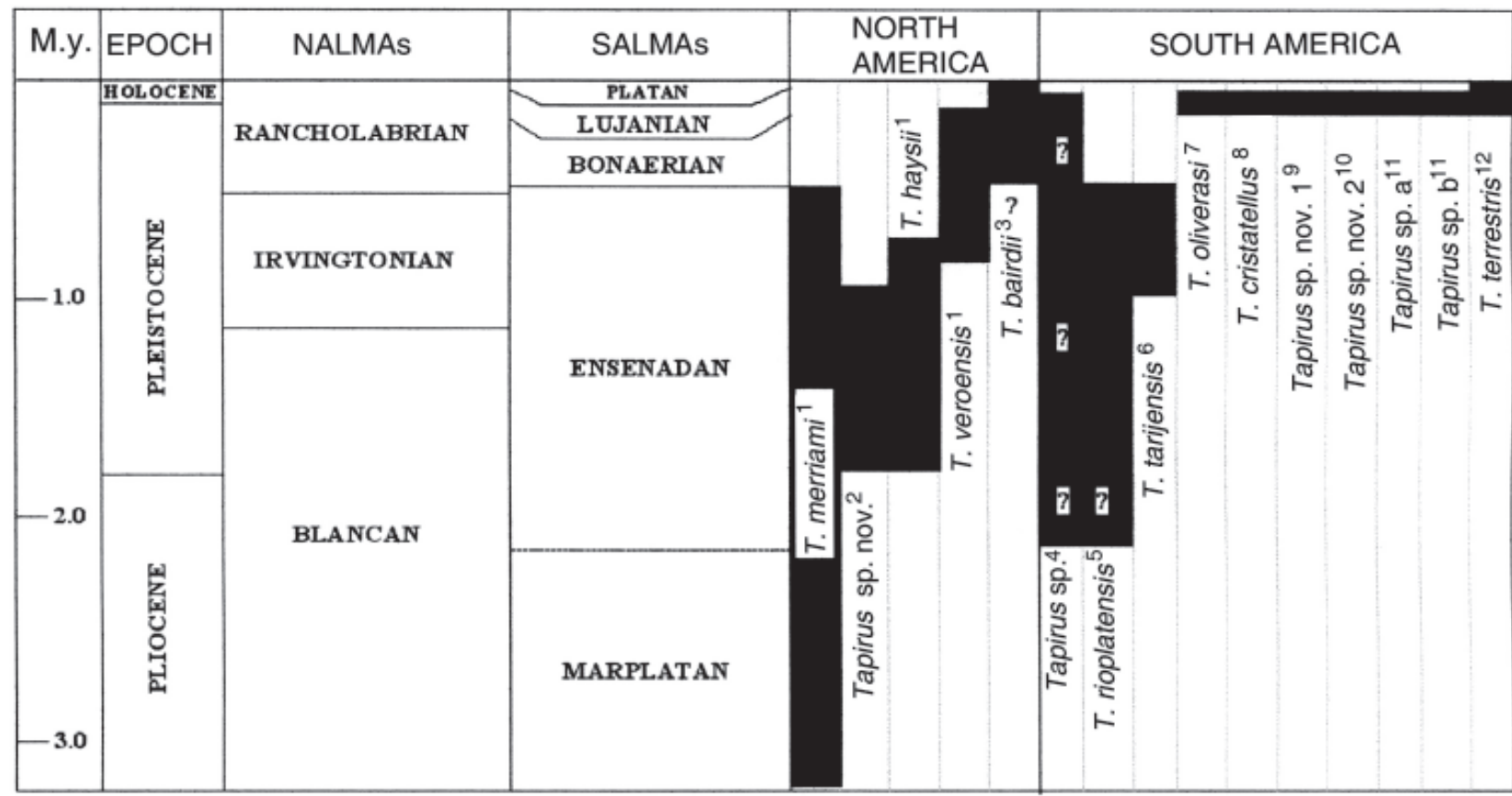

Figure 1. Stratigraphic distribution of genus Tapirus for North and South America during the Pliocene and Quaternary. Data based on: 1 Hulbert (1995); 2, Hulbert (1999); 3, Arroyo-Cabrales et al. (1996); 4, Tonni (1992); 5, Cattoi (1957); 6, Ameghino (1902); 7, Ubilla (1983); 8. Winge (1906); 9, Holanda et al. (2004); 10, Ferrero \& Noriega (2003); 11, this paper; 12, Nowak (1997).

\section{COLLECTING LOCALITIES}

Araras/Periquitos, Madeira River, Rondônia. The material was collected during the 1980s during the gold rush in Rondônia, in the locality of Araras/Periquitos, at the right margin of the Madeira River $\left(10^{\circ} 03^{\prime} 01^{\prime}\right.$ 'S, 65¹9'31'W), Nova Mamoré, Rondônia (Figure 2B). The outcrops there were included in the Jací-Paraná Formation by Adamy \& Romanini (1990) and Adamy \& Pereira (1991), but recently Rizzotto \& Oliveira (2004) recognized a new unit, the Rio Madeira Formation, for them and restricted the Jací-Paraná Formation to the finer and more recent deposits along the Madeira River. The Rio Madeira Formation is composed of fluvial sediments beginning with a basal conglomerate with sandy and calcareous matrix, frequent manganese and carbonaceous material, and vegetal remains, which received the local name of "mucururu." All the vertebrate remains with stratigraphic data come from this level. Above it the unit follows with ferruginous unconsolidated sands, mostly coarse to medium, sometimes with cross-beding. Paleochannel deposits are frequent and the sedimentology suggests that the river regime was significantly different from the present river, which has much more energy.

The faunistic association found at Araras/Periquitos is mainly made up of extinct taxa like Eremotherium, Glyptodon, Toxodon, Mixotoxodon, Stegomastodon, Holmesina, Neochoerus, and others (Góis et al., 2004; Nascimento et al., 2003, 2004; Porto et al., 2004). Some genera with living representatives, like Inia, Trichechus and Tapirus are known, but the species are extinct ones. Cozzuol (1999) suggested that the age of the association cannot be younger than late Pleistocene. An analysis of the palinological content indicates a dominance of wet forest elements (Cozzuol et al., 2004). According to Absy \& van der Hammen (1976) and van der Hammen \& Absy (1993) in two localities of Rondônia, the wet forest was dominant between 55,000 and 26,000 years ago, corresponding to the middle Pleniglacial, and again after 13,000 years ago, with an intermediate period of aridity, dominated by grasses corresponding to the Last Glacial Maximum (LGM). Combining data from fauna and palynology, it is possible to infer that the faunal association lived during middle Pleniglacial times, probably between 45,000 and 30,000 years ago.

Torre da Lua and Arenal, Juruá River, Acre. The other specimens studied here come from two localities along the upper Juruá River, Acre State: Torre da Lua ( $9^{\circ} 13^{\prime} 52^{\prime \prime}$, $\left.72^{\circ} 42^{\prime} 39^{\prime \prime} \mathrm{W}\right)$ and Arenal (9 $\left.9^{\circ} 12^{\prime} 48^{\prime \prime} \mathrm{S}, 72^{\circ} 41^{\prime} 34^{\prime \prime} \mathrm{W}\right)$ (Figure 2). This region was extensively studied, geologically and paleontologically, by Simpson \& Paula-Couto (1981), based on field work conducted by the first author and others in 1956. More recently, Latrubesse \& Rancy (1998) conducted another survey and produced $\mathrm{C}^{14}$ dates for several localities. The geologic description of the late Pleistocene sediments largely matches the one described above for Araras/Periquitos, and as in it, most of the fauna comes from the conglomerate unit. The described fauna is basically the same in both areas, as was shown by Nascimento et al. $(2003,2005)$. Radiocarbon dates are between 30,000 and 40,000 year, which are also consistent with data from Rondônia. 


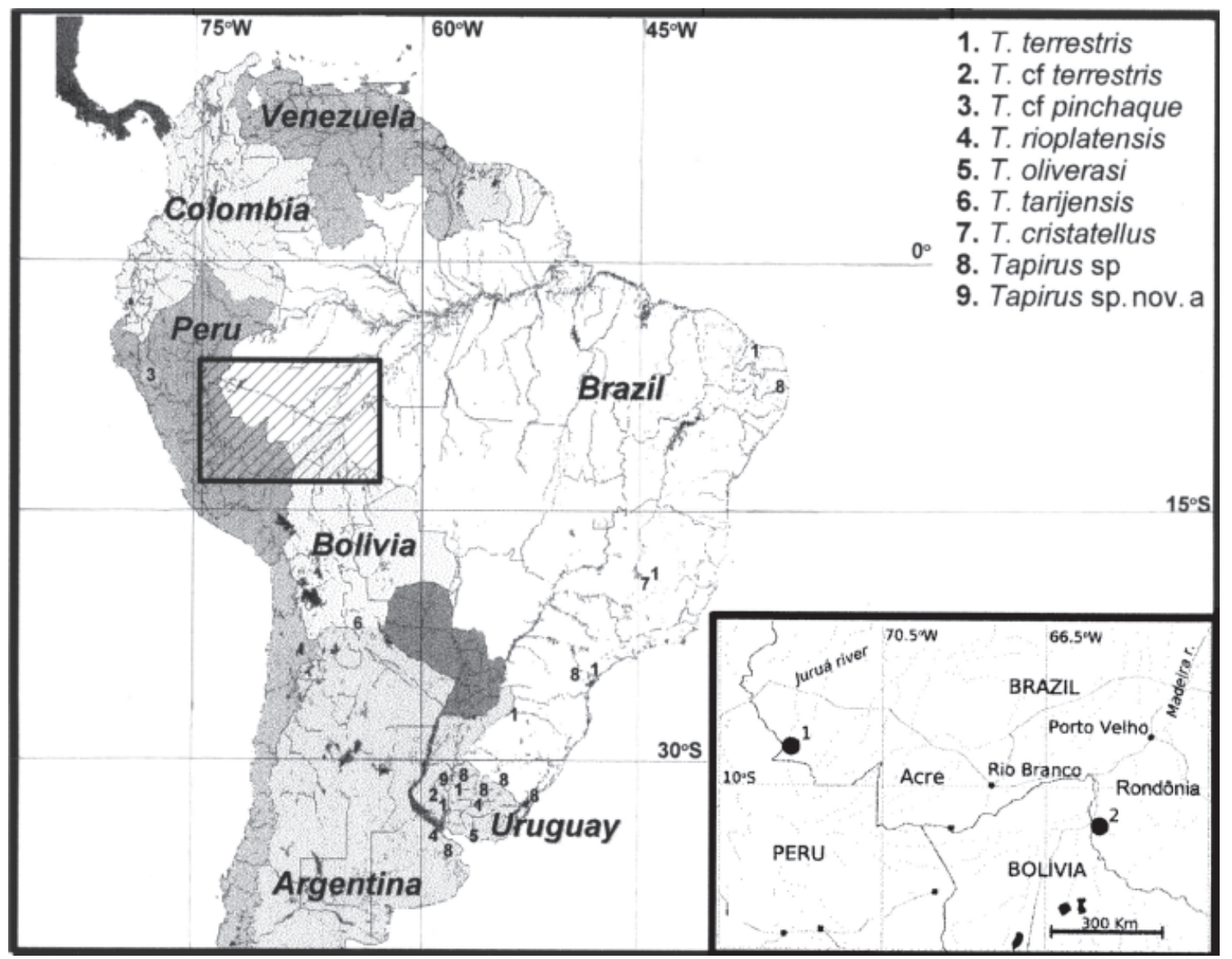

Figure 2. Map of South American with fossil records of the genus Tapirus. The dashed area is detailed showing the localities discussed in the text: Arenal and Torre da Lua (1) in Acre; and Araras (2) in Rondônia.

\section{MATERIAL AND METHODS}

The specimens under study consist in three partial right dentaries: a young specimen with deciduous dentition, a young specimen with the uneruped $\mathrm{m} 2$, and a fully mature specimen with heavily worn molars. Comparative material used here includes specimens of T. terrestris and T. bairdii.

The procedures for the descriptive analysis follows Hatcher (1896) and Simpson (1945). For the morphometric analysis, five measurements were made: tooth length (L), width of anterior loph (AW) width of posterior loph (PW), dentary width and dentary heigh at dp4/p4 level. Measurements were taken in millimeters with a manual caliper of $0.05 \mathrm{~mm}$ precision. For premolars we measured the posterior loph and for molars the anterior one.

Morphometric data from T. haysii, T. veroensis, and South American species including $T$. terrestris (both young and adult) were taken from Simpson (1945), Cattoi (1957), Ubilla (1983, 1996), Tonni (1992), Hulbert (1995) and Czaplewski et al. (2002).The statistical analysis was conducted using the latest available version of Palaeontological Statistics-PAST (Hammer et al., 2001).

Abbreviations. MERO, Museu Estadual de Rondônia, Porto Velho; UFAC, Laboratório de Pesquisas Paleontológicas, Universidade Federal do Acre, Rio Branco; ULBRA, Universidade Luterana do Brasil, Ji-Paraná; MLP, Museo de
La Plata, La Plata, Buenos Aires; UNIR, Laboratório de Biologia Evolutiva, Universidade Federal de Rondônia, Porto Velho; SALMA, South American Land Mammal Age; p, premolar; $\mathbf{m}$, molar.

\section{REVIEW OF THE SOUTH AMERICAN RECORDS OF TAPIRUS}

The oldest South American record for the genus Tapirus is from Ensenadan SALMA (late Pliocene - early to middle Pleistocene, Cione \& Tonni, 1996; Nabel et al.,2000; Ferrero \& Noriega, 2003), arriving on this continent as part of the GABI. Previous mention of the genus for the Uquian SALMA (Pascual et al., 1966; Marshall et al., 1984) are due to misinterpretation of the stratigraphy and confusion of units (Cione \& Tonni, 1996).

At least four extinct species have been described for South America (Figure 1). Ameghino (1902) described $T$. tarijensis based on a mandibular fragment with p2-4, supposedly with teeth more robust and mandibular ramus deeper than $T$. terrestris. Winge (1906) described $T$. cristatellus, from the late Pleistocene deposits of Lagoa Santa, Minas Gerais, based on cranial, dental and postcranial remains. This species was later considered a synonym of $T$. terrestris (Paula Couto, 1979), but recently Cartelle (1999), based on new material, supported its validity. Cattoi (1957) described $T$. rioplatensis on a partial mandible with $\mathrm{p} 3-\mathrm{m} 1$, 
significantly larger and more robust than T. terrestris. Ubilla (1983) described T. oliverasi, from the Pleistocene of Uruguay, based on a partial mandible with $\mathrm{m} 1-3$. It is significantly larger than $T$. terrestris but smaller that $T$. rioplatensis. Other nominal species of Tapirus described for the Pleistocene of South America, T. dupuyi (C. Ameghino, 1916) and T. australis Rusconi, 1928, are presently considered invalid and assigned to T. terrestris or Tapirus sp. (Ubilla, 1983; Tonni, 1992).

Tapirus terrestris was recorded for the late Pleistocene of Argentina, in the Departamento de Colón, Entre Ríos Province (Tonni, 1992) and for Brazil, in the late Pleistocene of Minas Gerais (Paula Couto, 1979, Cartelle, 1999), São Paulo (Paula Couto, 1980), Rio Grande do Norte (Porpino \& Santos, 2003) and Rio Grande do Sul states (Souza Cunha, 1959).

Records of undetermined species of Tapirus are relatively frequent, the most important being those in the Pleistocene of Uruguay (Ubilla, 1983), in Dom Pedrito and Santa Vitória do Palmar, Rio Grande do Sul (Holanda et al., 2005), in the Pleistocene of calcareous caves of Cerro Azul, Paraná ( Sedor et al., 2004), from several Pleistocene localities along the upper Juruá River, Acre (Paula Couto, 1983; Simpson \& Paula Couto, 1981; Rancy, 1981). Two apparently new species are being described for Brazil (Holanda et al., 2004) and Argentina (Ferrero \& Noriega, 2003, 2005).
All the fossil specimens of Tapirus reported so far are in the size range of $T$. terrestris or larger. The larger than $T$. terrestris morphotype includes several species, like $T$. rioplatensis, T. oliverasi and T. tarijensis.

\section{SYSTEMATIC PALEONTOLGY \\ Order PERISSODACTYLA Owen, 1848 \\ Suborder CERATOMORPHA Wood, 1937 \\ Superfamily TAPIROIDEA Gill, 1872 \\ Family TAPIRIDAE Bernett, 1830 \\ Genus Tapirus Brünnich, 1772 \\ Tapirus sp. a}

Material. MERO-PV-002, right dentary (Figure 3G, H, K). Locality. Araras/Periquitos, Nova Mamoré, Rondônia.

Description. right dentary of a young specimen with p2-m1 (the dp4 is still present and the definitive $\mathrm{p} 4$ is already formed under it, detected by $X$ ray examination). The $m 2$, still unerupted, is visible inside its crypt. All the teeth, deciduous and definitive, are smaller that the respective teeth in $T$. terrestris (Figure $3 \mathrm{H}, \mathrm{I}$ ).

Anteriorly the dentary is broken at the beginning of the symphysis, and canines and incisors are missing. The posterior end of the mandible is complete, including the
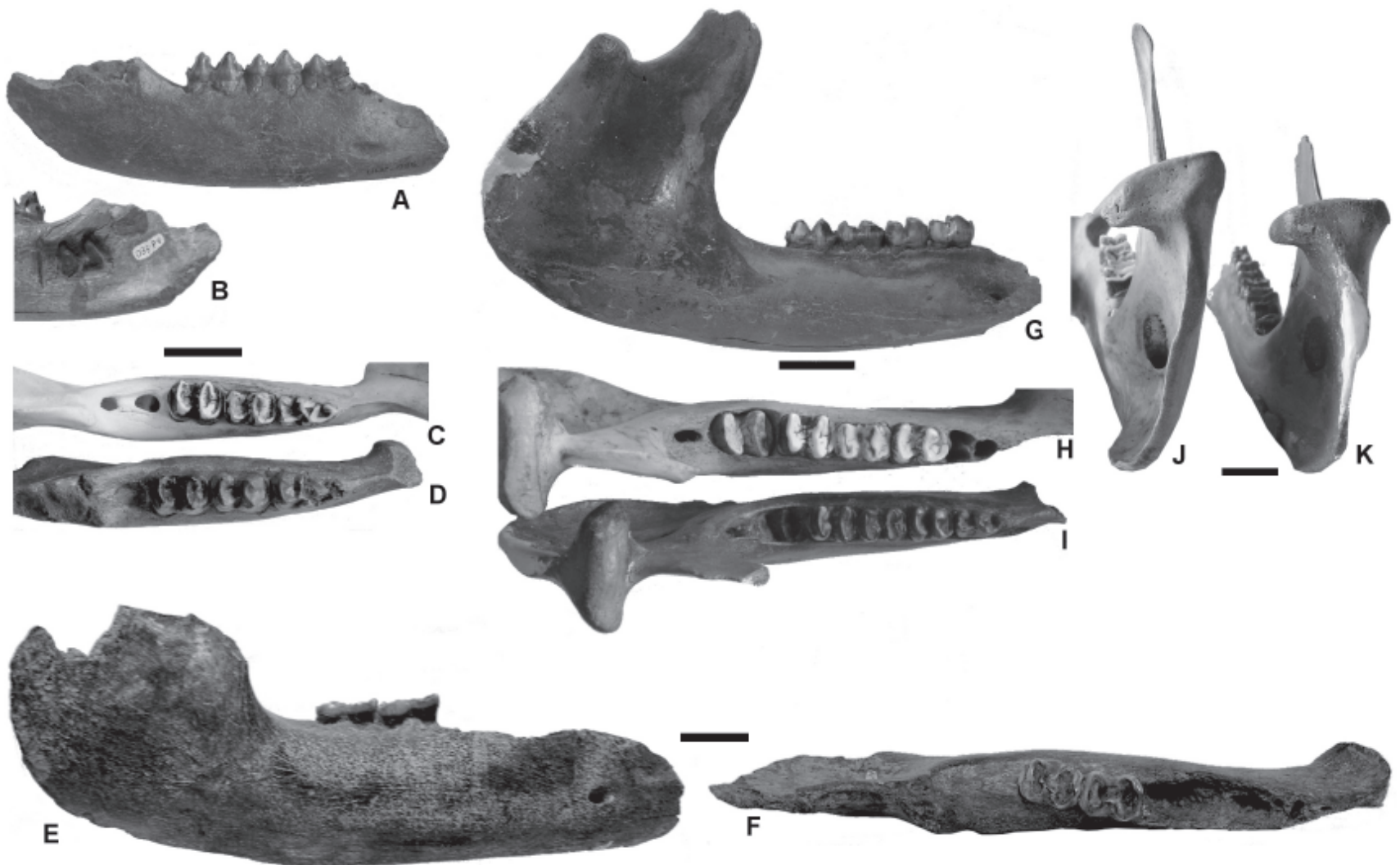

Figure 3. South American specimens of Tapirus, A-B and D, UFAC-035-PV; partial right dentary of a juvenile with dp2-4 and unerupted m1: A, lateral view; B, detail of the exposed unerupted $\mathrm{m} 1$ in medial view; C, occlusal view; E-F, UFAC-034-PV; partial right dentary of an old specimen with m2-3: E, lateral view; F, occlusal view; G, I, K, MERO-PV-002, almost complete right dentary of a young adult with p2-3, dp4, $\mathrm{m} 1$ and unerupted m2: G, lateral view; I, oclusal view, K, posterior view; D, UNIR-M067; T, terrestris, juvenile, occlusal view; H-J, UNIRM083, T, terrestris, young adult: $\mathbf{H}$, occlusal view; J, posterior view. Scale bars $=3 \mathrm{~cm}$ 
Table 1. Measurements $(\mathrm{mm})$ of the definitive dentition in UFAC034-PV, MERO-PV-002 and T. terrestris.

\begin{tabular}{l|ccc|c|c} 
& \multicolumn{3}{|c|}{ T. terrestris } & UFAC & MERO- \\
\cline { 2 - 4 } & $\mathrm{n}$ & $\mathrm{x}$ & $\mathrm{s}$ & 034-PV & PV-002 \\
\hline p2-L & 5 & 21.41 & 0.90 & $?$ & 19.00 \\
p2-W & 5 & 12.86 & 1.16 & $?$ & 11.00 \\
p3-L & 5 & 20.93 & 1.69 & $?$ & 18.00 \\
p3-AW & 5 & 14.28 & 0.71 & $?$ & 14.20 \\
p3-PW & 5 & 16.09 & 1.11 & $?$ & 13.20 \\
p4-L & 5 & 20.99 & 1.52 & $?$ & - \\
p4-AW & 5 & 15.66 & 0.84 & $?$ & - \\
p4-PW & 5 & 16.29 & 1.65 & $?$ & - \\
m1-L & 5 & 21.09 & 1.43 & $?$ & 19.00 \\
m1-AW & 5 & 16.37 & 0.80 & $?$ & 15.00 \\
m1-PW & 5 & 15.47 & 0.81 & $?$ & 13.50 \\
m2-L & 4 & 23.36 & 1.47 & 24.30 & $?$ \\
m2-AW & 4 & 17.92 & 0.61 & 18.20 & $?$ \\
m2-PW & 4 & 17.11 & 0.73 & 18.20 & $?$ \\
m3-L & 2 & 24.00 & 0.20 & 24.80 & $?$ \\
m3-AW & 2 & 18.72 & 0.42 & 17.80 & $?$ \\
m3-PW & 2 & 16.22 & 0.72 & 17,20 & $?$ \\
\hline
\end{tabular}

Table 2. Measurements $(\mathrm{mm})$ of the deciduous dentition in UFAC035-PV, MERO-PV-002 and T. terrestris.

\begin{tabular}{l|ccc} 
& T. terrestris & $\begin{array}{c}\text { UFAC 035- } \\
\text { PV }\end{array}$ & $\begin{array}{c}\text { MERO-PV- } \\
\mathbf{0 0 2}\end{array}$ \\
\hline dp2-L & 23.50 & 26.00 & - \\
dp2-W & 12.50 & 14.30 & - \\
dp3-L & 19.80 & 21.50 & - \\
dp3-AW & 13.90 & 14.80 & - \\
dp3-PW & 13.30 & 14.80 & - \\
dp4-L & 21.00 & 23.00 & 19.50 \\
dp4-AW & 15.00 & 16.00 & 13.30 \\
dp4-PW & 14.00 & 16.00 & 13.00 \\
\hline
\end{tabular}

coronoid process which is only a little abraded at the top. The medio-lateral axis of the mandibular condyle is perpendicular to the coronoid process (Figure $3 \mathrm{~K}$ ); this differs from $T$. terrestris in which the medial end is lower than the lateral end (Figure 3J). The mental foramen opens before the $\mathrm{p} 2$. In MERO-PV-002 the coronoid process in much lower than in animals of the same age of $T$. terrestris (Figure 3J, K). Also, the angular process, which is strongly curved medially in $T$. terrestris, is essentially straight in MERO-PV-002 (Figure 3J, K). The tooth measurements for this specimen can be found in Tables 1 and 2 .

\section{Tapirus sp. b}

Material. UFAC-034-PV, right dentary, described and identified by Rancy (1981) as Tapirus sp (Figure 3E-F).

Localities. Arenal, upper Juruá River, Acre.

Description. Right dentary of an old specimens with $\mathrm{m} 2$ and $\mathrm{m} 3$ very worn and the alveoli of p2-4 and m1. Most of the ascending process and symphysis are missing. The mental foramen opens just below the alveolus of the $\mathrm{p} 2$. The mandible is more robust than $T$. terrestris, particularly the mandibular thickness (compare Figure 3F, H). In medial view the mandibular foramen opens at the same level of the tooth row. Behind the $\mathrm{m} 3$ a large and slightly concave area is observed between the tooth and the base of ascending ramus. The tooth measurements for this specimen can be found in Table 1.

Material. UFAC-035-PV, right dentary, described and identified by Rancy (1981) as Tapirus sp (Figure 3 A-C).

Localities. Torre da Lua, upper Juruá River, Acre.

Description. right dentary of a very young individual with dp2-4 and unerupted $\mathrm{m} 1$ visible through a window opened in the bone on the lingual side (Figure 3B). The ascending process and symphysis are missing. The mental foramen

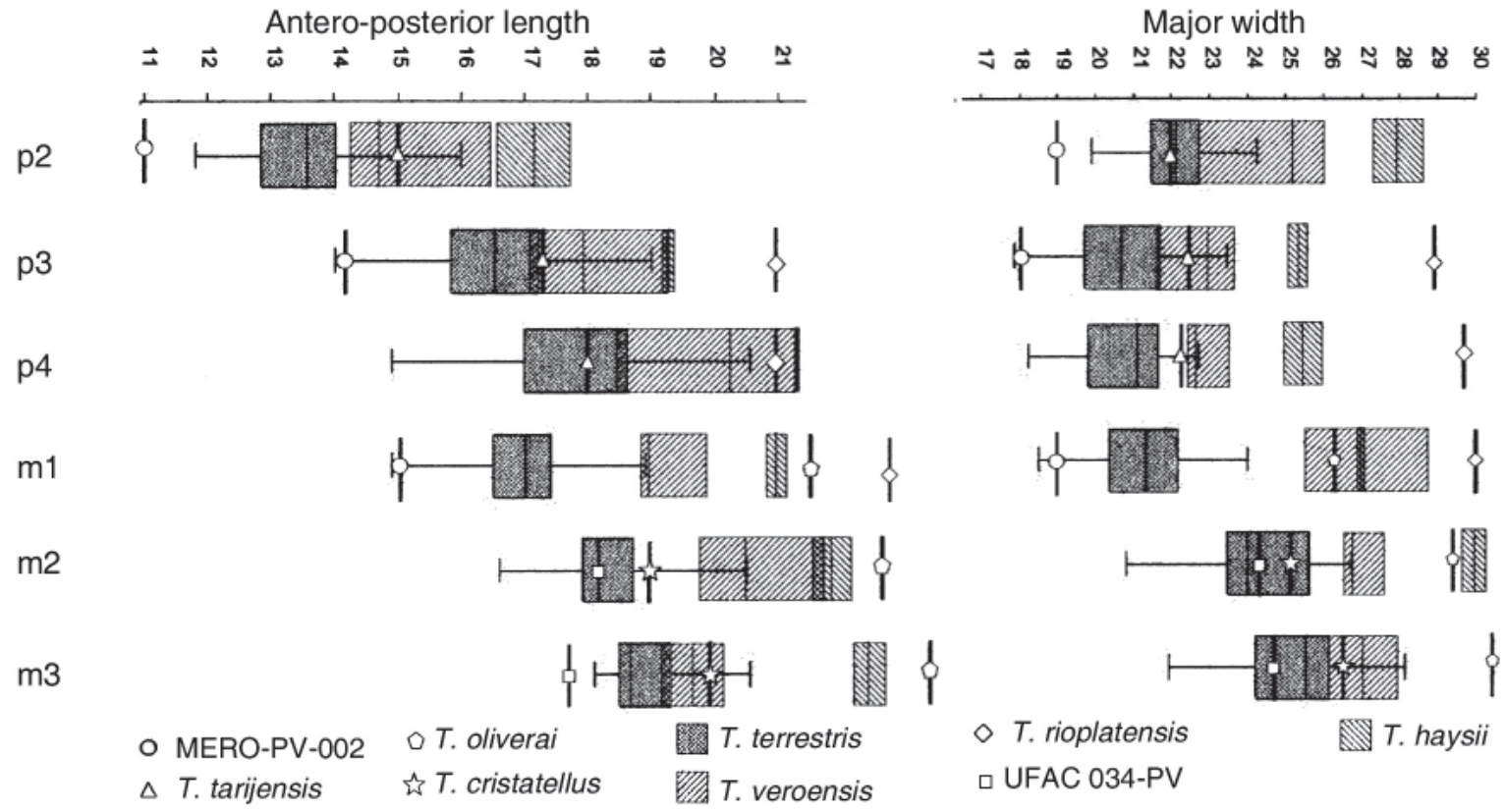

Figure 4. Box-plot graph of definitive dentition dimensions (in $\mathrm{mm}$ ) for fossil and living species of genus Tapirus. 


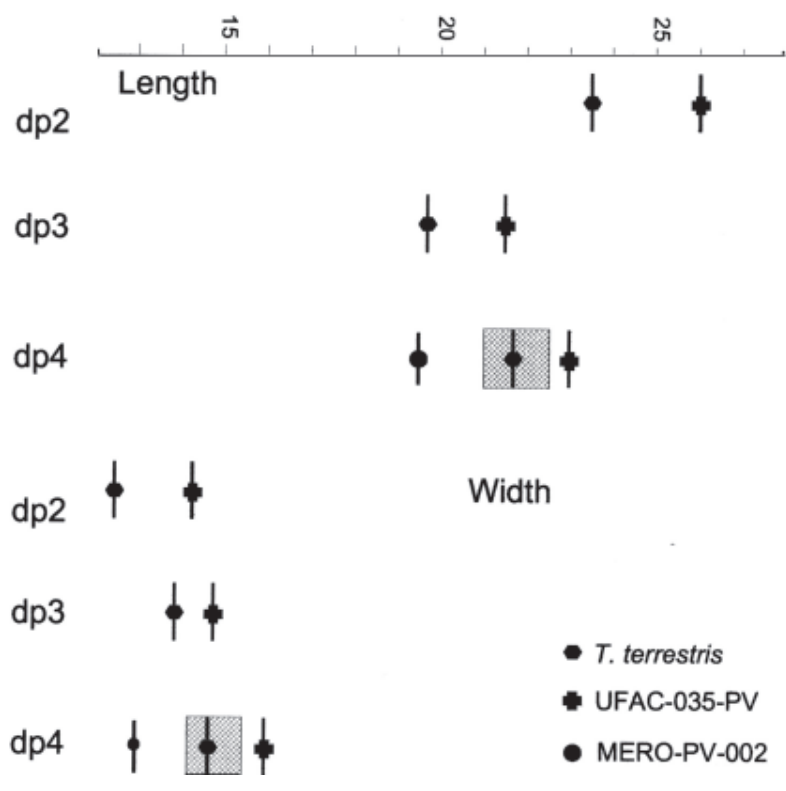

Figure 5. Box-plot graph of deciduous dentition dimensions (in $\mathrm{mm}$ ) for fossil and living species of genus Tapirus.

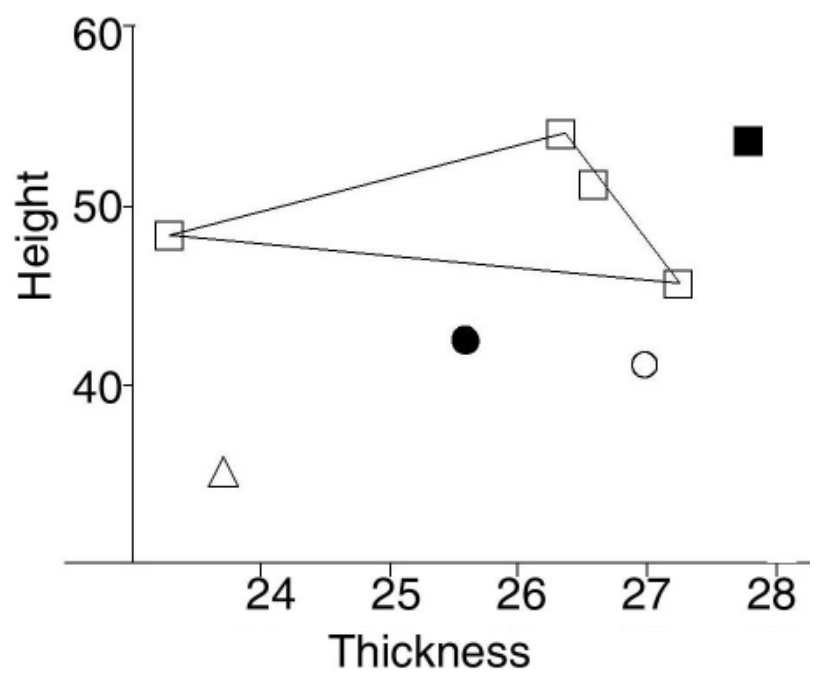

Figure 6. Graph of thickness versus height of the dentary (in $\mathrm{mm}$ ) in species of Tapirus. The measurements were taken at level of dp4/p4: adult $T$. terrestris (white square), UFAC-034-PV (black square), UFAC-035-PV (white circle), MERO-PV-002 (black circle), juvenile $T$. terrestris (triangle).

opens just below the trigonid of dp2. The $\mathrm{p} 2$ trigonid is patially broken. Both dp3 and dp4 are molariform, with mesial cingules well developed. The tooth measurements for this specimen can be found in Table 2 .

\section{MORPHOMETRIC ANALYSIS}

The ratio of dentary width versus height was considered in relation to the dental age of the specimens, discriminating juveniles (only premolars present) and adults (premolars and molars present).

UFAC-034-PV is more robust than T. terrestris in the mandibular width. UFAC-035-PV is larger both in tooth and dentary size than the equal-aged individual of $T$. terrrestris (Figure 5).
Deciduous and definitive teeth were considered separately since the deciduous premolars tend to be more molar-like than the definitive premolars.

Dental dimensions of $T$. haysii and T. veroensis are larger that $T$. terrestris (Figure 4). MERO-PV-002 is the smallest of the three specimens. UFAC-035-PV, a very young animal, is consistently and significantly larger than $T$. terrestris at the same developmental stage (Figure 3A-C; Figure 5). UFAC 034-PV has a more robust dentary, especially in the mediolateral thickness (Figure 6), but dental measures are in the range of T. terrestris variation except the $\mathrm{m} 3$ width, which is smaller than expected for this species (Figure 4).

\section{CONCLUSIONS}

Our morphometric analysis of the dentaries UFAC-034PV and UFAC-035-PV, agrees with that of Rancy (1981), who stated that they are more robust than $T$. terrestris. On the other hand, the new specimen, MERO-PV-002, is significantly smaller and delicate, both in jaw robustness and dental size.

This observation suggests that the Acre and Rondônia specimens belong to different species, and both of them are different from T. terrestris. Consequently, it may be inferred that during the late Pleistocene in southwestern Amazonia two Tapirus morphotypes existed, both different from the living species. One of them is a more robust animal, represented by UFAC 034-PV and UFAC 035-PV from Acre. The other one, represented by MERO-PV-002, from Rondônia, is the first smaller and delicate Tapirus form reported for South America.

Most of the previous nominal and valid species described for the genus in South America are described as larger than $T$. terrestris in general size or dental size and proportions (Ameghino, 1902; Cattoi, 1957; Ubilla, 1983; Tonni, 1992; Cartelle, 1999; Ferrero \& Noriega, 2003, 2005), even if this size can not always be proved by quantitative analysis (Ubilla, 1983; Tonni, 1992). Also, besides the smaller size compared with individuals of the same developmental stage, this gracile form can be differentiated from $T$. terrestris in the relative position of the mandibular condyle, the shorter coronoid process, and absence of inflexion of the angular process of the mandible (Figure 3 G-K).

A third morphotype, in the size and proportion range of the living T. terrestris, was present in Rondônia and Acre in the Pleistoce. Most of the Acre specimens in this size range are referred to the living species and are based on isolated teeth. The Rondônia specimens, consisting of two partial skulls, are under study $(\mathrm{ECH})$ and may represent a new species (Holanda et al., 2004, 2005).

\section{ACKNOWLEDGMENTS}

The authors are indebted to the Laboratório de Pesquisas Paleontógicas (UFAC) and Museu do Estado de Rondônia (MERO) for loaning the studied specimens. Alceu Ranzi allowed us to use the specimen studied in his unpublished Thesis. For providing help to access the collections we thank 
Teófilo L. de Lima (ULBRA, Ji-Paraná) and Mariano Merino (MLP). The Brazilian research council (CNPq) supported the project (proc. 551351/01-2) that made possible this work.

\section{REFERENCES}

Absy, M.L. \& van der Hammen, T. 1976. Some paleocological data from Rondônia, southern part of the Amazon Basin. Acta Amazonica, 6(3):293-299.

Adamy, A. \& Pereira, L.A.C. 1991. Projeto Ouro e Gemas - Frente Rondônia. Relatório Anual. Companhia de Pesquisa de Recursos Minerais, p. 8-35.

Adamy, A. \& Romanini, S.J. (Org.) 1990. Geologia da região Porto Velho-Abunã. Folhas Porto Velho (SC.20-V-B-V), Mutumparaná (SC.20-V-C-VI), Jaciparaná (SC.20-V-D-I), Abunã (SC.20-V-C-V), estados de Rondônia e Amazonas. Programa de levantamentos geológicos básicos do Brasil, DNPM/ CPRM, Brasília, 273p.

Ameghino, F. 1902. Notas sobre algunos mamíferos fósiles nuevos o poco conocidos del Valle de Tarija. Anales del Museo de Historia Natural de Buenos Aires, 3:225-261.

Arroyo-Cabrales, J.; Polaco, O.J.; Alvarez, T. \& Johnson, E. 1996. New records of fossil tapir from northeastern Mexico. Current Research in the Pleistocene, 13:93-94.

Ashley, M.V.; Norman, J.E. \& Stross, L. 1996. Phylogenetic analysis of the perissodactylan Family Tapiridae using mitochondrial cytochrome c oxidase (COII) sequences. Journal of Mammalian Evolution, 3(4):315-325.

Bodmer, R.E. \& Brooks, D.M. 1997. Status and Action Plan of the Lowland Tapir (Tapirus terrestris). In: D.M. Brooks; R.E. Bodmer, \& S. Matola. Tapirs-Status Survey and Conservation Action Plan, IUCN, Cambridge, 164 p.

Cartelle, C. 1999. Pleistocene mammals of the Cerrado and Caatinga of Brazil. In: J.F. Eisenberg \& K.H. Redford (eds.) Mammals of the Neotropics - The Central Neotropics, The University of Chicago Press, vol. 3, p. 27-46.

Cattoi, N. 1957. Una especie extinguida de Tapirus Brisson ( $T$. rioplantensis nov. sp.). Ameghiniana, 1(3):15-21.

Cione, A.L. \& Tonni, E.P. 1996. Reassessment of the PliocenePleistocene continental times scale of Southern South America. Correlation of the type Chapadmalalan with Bolivian sections. Journal of South American Earth Sciences, 9(3/4):221-236.

Cozzuol, M.A. 1999. Mamíferos acuáticos y la antigüidad de los depositados cuaternários del Alto Río Madeira (Rondônia, Brasil). In: CONGRESSO INTERNACIONAL EVOLUCIÓN NEOTROPICAL DEL CENOZOICO, 1999. Programa y Resúmenes, La Paz, Academia Nacional de Ciencias Boliviana, p. 18 .

Cozzuol, M.A.; Latrubesse, E.M. \& Silva, S.A.F. 2004. Estudo de viabilidade para implementação de usinas hidrelétricas no rio Madeira. Relatório Parcial. Paleontologia. -UNIR/RIOMAR/ FURNAS, 56p. (Relatório inédito)

Czaplewski, N.J; Puckette, W.L. \& Russel, C. 2002. A Pleistocene tapir and associated mammals from the southwestern Ozark Highland. Journal of Cave and Karst Studies, 64(2):97-107.

Downer, C.C. 1997. Status and Action Plan of the Mountain Tapir (Tapirus pinchaque). In: D.M. Brooks; R.E. Bodmer \& S. Matola (eds.) Tapirs-Status Survey and Conservation Action Plan, IUCN, Gland, p. 10-22.

Eisenberg, J. F. \& Redford, K. H. 1989. Mammals of the Neotropics - The Central Neotropics: Ecuador, Peru, Bolivia, Brazil. In: J.F. Eisenberg \& K.H. Redford (eds.) Mammals of the Neotropics
- The Central Neotropics, The University of Chicago Press, vol. 3, p.327-330.

Ferrero, B.S. \& Noriega, J.I. 2003. El registro fósil de los tapires (Perissodactyla: Tapiridae) en el Pleistoceno de Entre Ríos. Ameghiniana, 40(4)-S:84R.

Ferrero, B.S. \& Noriega, J.I. 2005. Tapires del Pleistoceno de Entre Ríos (Perisodactyla:Tapiridae). Análisis filogenética preliminar. In: JORNADAS ARGENTINAS DE PALEONTOLOGÍA DE VERTEBRADOS, 21, 2005. Resúmenes, Neuquen, Plaza Huincul.

Góis, F.; Nascimento, E.R. do; Porto, A.S.; Holanda, E.C. \& Cozzuol, M.A. 2004. Ocorrências de Cingulata dos gêneros Kraglievichia e Holmesina do Terciário e Quaternário da Amazônia Sul-Ocidental. Ameghiniana, 41(4)-S:49

van der Hammen, T. \& Absy, M.L. 1993. Amazonia during the last glacial. Palaeogeography, Palaeoclimatology, Palaeoecology, 109:247-261.

Hammer, O.; Harper, D.A.T. \& Ryan, P.D. 2001. PAST: Paleontological Statistics Software Package for Education and Data Analysis. Paleontologia Electronica 4(1): 9pp.

Hatcher, J.B. 1896. Recent and fossil tapirs. The American Journal of Science (Fourth Series), 1(3):161-184.

Holanda, E.C; Porto, A. S.; Nascimento, E. R. Do; Góis, F. \& Cozzuol, M. A. 2004. Registros do gênero Tapirus (Mammalia, Perissodactyla) do Pleistoceno da Amazônia Sul-Ocidental. Ameghiniana, 41(4)-S:51R

Holanda, E.C.; Ribeiro, A.M.; Ferigolo, J. \& Cozzuol, M.A. 2005. Novos registros de Tapirus Brünnich, 1771 (Mammalia, Perissodactyla) para o Quaternário do Brasil. In: CONGRESSO LATINOAMERICANO DE PALEONTOLOGIA DE VERTEBRADOS, 2, 2005. Boletim de Resumos, Rio de Janeiro, UFRJ, p.136.

Hulbert Jr, R. C. 1995. The giant tapir, Tapirus haysii, from Leisey Shell Pit $1 \mathrm{~A}$ and other Florida Invingtonian localities. Bulletin of Florida Museum of Natural History, p. 515-551.

Hulbert Jr, R.C. 1999. Nine million years of Tapirus (Mammalia, Perissodactyla) from Florida. Journal of Vertebrate Paleontology, 19(3):53A.

Latrubesse, E.M. \& Rancy, A. 1998. The late Quaternary of the Upper Juruá River, southwestern Amazonia, Brazil: geology and vertebrate paleontology. Quaternary of South America and Antarctic Peninsula, p. 27-46.

Marshall, L.; Berta, A.; Hoffstetter, R.; Pascual, R.; Reig, O.; Bombin, M. \& Mones, A. 1984. Mammals and stratigraphy: geochronology of the continental mammal-bearing Quaternary of South America. Palaeovertebrata, Mémoire Extraordinaire, $76 \mathrm{p}$.

Nabel, P.E.; Cione, A. \& Tonni, E.P. 2000. Environmental changes in the Pampean area of Argentina at the Matuyama-Brunhes (C1r-C1n) Chrons boundary. Palaeogeography, Palaeoclimatology, Palaeoecology, 162:403-412.

Nascimento, E.R.; Porto, A.S.; Holanda, E.C.; Lima, F.G.; Cozzuol, M.A. 2003. A fauna local de mamíferos pleistocênicos das localidades de Araras/Periquitos e Taquara, Rondônia. In: CONGRESSO BRASILEIRO DE PALEONTOLOGIA, 18, 2003. Boletim de Resumos, Brasília, UnB, p. 206-207.

Nascimento, E.R.; Gois, F.; Porto, A.S.; Holanda, E.C. \& Cozzuol, M.A. 2004. Paleoecologia dos mamíferos do Pleistoceno da Amazônia Sul-Ocidental, Brasil. Ameghiniana, 41(4)-S:44R.

Nascimento, E.R.; Holanda, E.C.; Gois, F. \& Cozzuol, M.A. 2005. Inferências paleoambientais para os depósitos fossilíferos do Quaternário da Amazônia sul-ocidental, Brasil. In: CONGRES- 
SO BRASILEIRO DE PALEONTOLOGIA, 19, 2005. Resumos, Aracaju, Sociedade Brasileira de Paleontologia, CD.

Norman, J.E. \& Ashley, M. V. 2000. Phylogenetics of Perissodactyla and tests of the molecular clock. Journal of Molecular Evolution. 50:11-21.

Nowak, R. M. 1997. Walker's Mammals of the World on-line 5.1. Johns Hopkins University Press.

Pascual, R.; Ortega Hinojosa, E.J.; Gondar, D. \& Tonni, E.P. 1966. Paleontografía Bonaerense. Comisión de Investigaciones Cientificas, Província de Buenos Aires, 4:1-202.

Paula Couto, C. 1979. Tratado de Paleomastozoologia. Academia Brasileira de Ciências, Rio de Janeiro, 590p.

Paula Couto, C. 1980. Fossil mammals of the Pleistocene of Jacupiranga State of São Paulo, Brazil. Anais da Academia Brasileira de Ciências; 52:135-142.

Paula Couto, C. 1983. Fossil mammals from the Cenozoic of Acre, Brazil. VII-Miscellanea. Iheringia, 8:101-120.

Porpino, K.O. \& Santos, M.F.C.F. dos. 2003. Novos registros de Artiodactyla e Perissodactyla para o Lajedo da Escada, Baraúna/ RN. In: CONGRESSO BRASILEIRO DE PALEONTOLOGIA, 18, 2003. Boletim de Resumos, Brasília, UnB, p. 226.

Porto, A.S.; Góis, F.; Nascimento, E.R. do; Holanda, E.C. \& Cozzuol, M.A. 2004. Xenarthra Pilosa (Edentata) do Quaternário do Estado de Rondônia. Ameghiniana, 41(4)S:60R.

Radinsky, L.B. 1965. Evolution of the tapiroid skeleton from Heptodon to Tapirus. Bulletin of the Museum of Comparative Zoology, 134(3):69-106.

Rancy, A. 1981. Mamíferos fósseis do Cenozóico do Alto JuruáAcre. Programa de Pós-Graduação em Geociências, Universidade Federal do Rio Grande do Sul, Dissertação de Mestrado, $122 \mathrm{p}$.

Rizzotto, G.J. \& de Oliveira, J.G.F. 2004. Estudo de viabilidade para implementação de usinas hidrelétricas no rio Madeira. Relatório Parcial. Geologia, Recursos Minerais, Atividade Garimpeira e Hidrogeologia. CPRM-RO/FURNAS, Porto Velho. (Relatório inédito)

Sedor, F.A.; Born, P.A. \& Santos, F.M.S. 2004. Fósseis pleistocênicos de Scelidodon (Mylodontidae) e Tapirus (Tapiridae) em cavernas paranaenses (PR, sul do Brasil). Acta Biologica Paraense, 33:121-128.

Simpson,G.G. 1945. Notes on Pleistocene and recent Tapirs. Bull. Am. Mus. Hist. Nat, 86:34-81.

Simpson, G.G. \& Paula Couto, C. 1981. Fossil mammals from de Cenozoic of Acre, Brazil III - Pleistocene Edentata Pilosa, Proboscidea, Sirenia, Perissodactyla and Artiodactyla. Iheringia, 6:11-73.

Souza-Cunha, F.L. 1959. Mamíferos do Pleistoceno do Rio Grande do Sul. I - Ungulados. DNPM, DGM, Rio de Janeiro, 47p.

Tonni, E.P. 1992. Tapirus Brisson, 1762 (Mammalia, Perissodactyla) en el Lujanense (Pleistoceno Superior-Holoceno Inferior) de la Provincia de Entre Rios, Republica Argentina. Ameghiniana, 29:3-8.

Tonni, E.P.; Cione, A.L. \& Figini, A.J. 1999. Predominance of arid climates indicated by mammals in the pampas of Argentina during the Late Pleistocene and Holocene. Palaeogeography Palaeoclimatology, Palaeocology, 147:257-281.

Ubilla, M. 1983. Sobre la presencia de tapires fósiles em el Uruguay (Mammalia, Perissodactyla, Tapiridae). Revista de la Facultad de Humanidades y Ciencias, 1(3):85-104.

Ubilla, M. 1996. Paleozoologia del Cuaternario continental de la Cuenca norte del Uruguay: biogeografía, cronología y aspectos climático-ambientales. Programa de Desarrolo en Ciências Básicas, Universidad de La República, Uruguay, Tese de Doutorado, $232 \mathrm{p}$.

Winge, H. 1906. Jordfundne og nulevende Hoydyr (Ungulata) fra Lagoa Santa, Minas Gerais, Brasilien. E. Mus. Lundii., 3:1-239.

Received in November, 2005; accepted May, 2006. 